\title{
Project Management Maturity: an Analysis with Fuzzy Expert Systems
}

\author{
Helder Jose Celani de Souza, Valerio Antonio Pamplona Salomon \\ Sao Paulo State University (UNESP), Guaratingueta, SP, Brazil
}

\section{Carlos Eduardo Sanches da Silva}

Federal University of Itajuba (UNIFEI), Itajuba, MG, Brazil

\section{Dimas Campos Aguiar}

Iochpe Maxion Wheels and Chassis Division, Cruzeiro, SP, Brazil

\begin{abstract}
In order to create proper conditions to make projects successful, a growing number of organizations are taking up the practice of assessing Project Management Maturity (PMM). PMM can be verified through a variety of models. This paper reports the results of a survey, which used the Kerzner Maturity model, of 101 Brazilian companies. The novel and scientific contribution of this paper is the use of a Fuzzy Expert System as a tool to deal with the model's subjectivity and to check the consistency of survey's responses. The methodological approaches of previous Project Management Maturity studies included only trivial statistical analysis and usually showed less accuracy in the final results than that of the current research. The present work innovates by introducing the use of intelligent techniques, such as Fuzzy Sets and Expert Systems, in the Project Management Maturity analysis.
\end{abstract}

Keywords: Project Management, Maturity, Expert Systems, Fuzzy Sets.

\section{Introduction}

The assessment of Project Management Maturity (PMM) is a growing practice in organizations and it can be verified with the development and use of several models for this purpose. In general, PMM is an organizational condition that allows successful projects. Project Management Maturity (PMM) is a measure of the competence of company's project managers. But, company's PMM can be affected by its working environment, and by the alignment between projects and company's results (Hartman and Skulmoski, 2000). According to Kerzner (2009), PMM is the implementation of a standard methodology and accompanying processes such that there is a high likelihood of repeated success.

The novel and scientific contribution of this paper is the use of a Fuzzy Expert System as a tool to deal with model's subjectivity and to check the consistency of survey's responses. Methodological approaches of previous Project Management 
Maturity researches only included trivial statistical analysis and usually show less accuracy for the final results. This way, the present work innovates when introduces the usage of intelligent techniques, as Fuzzy Sets and Expert Systems, in the Project Management Maturity analysis.

This paper reports results of a survey based on the Kerzner Maturity model and performed in Brazilian companies. The survey was supported by the Project Management Institute (PMI), a nonprofit professional organization. Based on the PMM model proposed by Kerzner (2001), a website was developed for the survey. At the end of 2009, project managers registered at the PMI's Sao Paulo Chapter were contacted. Even knowing that they will not be identified in the results, only 101 managers answered the questions of the survey. That is $7 \%$ of the total invited. One reason for the low rate of responses is that $56 \%$ of the invited project managers have less than five-year experience in Project Management (PM). So, they did not have consolidated interest and enough knowledge in PMM to take part of the survey. However, according to Hair et al. (2009), this sample size can be accepted.

The Kerzner model has five levels of PM Maturity, classified from 1 (lowest) to 5 (highest) and they are represented as steps of a ladder, as will be presented in Section 2. According to a crisp classification, 47\% of survey's respondents must be classified in level 1 of PMM. This is a frustrating result, since Level 1 is the PMM model's starting level. This result is even worst when comparing to another survey, made almost 10 years before in Northern California (Ibbs and Kwak, 2000). The PMM for those companies averaged 3.26, also in a scale from 1 to 5 .

In the Brazilian Survey some answers were inconsistent with the PMM model. That is, for instance, one company reached Level 4 of PMM, but, surprisingly it did not satisfy Level 3 requirements. The concept of inconsistency of PMM is also discussed in Section 2. To deal with inconsistent answers, a Fuzzy Expert System was developed and is showed in Section 3.

The work was organized to show in Section 2 the theoretical background of PMM models. In Section 3 a Fuzzy Expert System to be applied in the analysis of the PMM. In Section 4 the Fuzzy Expert System application using the data collected from the survey. And, in Section 5 conclusions and discussions.

\section{Project Management Maturity}

According to Kerzner (2003), PMM is an implementation of a standard methodology and accompanying processes such that there is a high likelihood of repeated successes. For Andersen and Jessen (2003), the concept of Maturity involves the measures of how close the organizations are of the perfect conditions to achieve their goals. In general, PMM is an organizational condition that allows successful projects. The measurement of PMM is performed by using models based on the 9 PM knowledge areas and organizational dimensions. The major existing models originated from the Capability Maturity Model (CMM) developed by Software Institute Engineering (SEI) at Carnegie Mellon University (CMU). The final result of a PMM assessment usually makes the organizations capable to identify key opportunities for PM improvements and increase the number of successful projects (Ibbs and Kwak, 2000). 
According to Hayes (2007) and Brookes and Clark (2009), the concepts of the PMM assessment models were originated from the fundamentals of total quality due to the direct relation to continuous improvement. The models are generally based on the use of five evolution levels represented graphically by a ladder and each step corresponds to a PMM stage to be reached by the organization. The PMM models have been applied recently in the organizations and developed by several authors and companies (Ibbs and Kwak, 2000; Hillson, 2003; Sawaya and Trapanese, 2004), and many of the existing PMM models are limited in scope and have been designed only to categorize the current behavior of the organization (Andersen and Jessen, 2003).

The Capability Maturity Model (CMM) was the first model introduced in the market motivated by US\$ 145 billion annual losses due failures in software development and new products projects delivery time accomplishments (Paulk et al., 1993; Chrissis et al., 2006). As reported by Jiang et al. (2004), the PMM assessment is an initiative driven by the need to achieve successful projects. The measurement of PMM often looks more subjective than objective because the focus is primarily on activities related to organizational structure, people, project teams, policies, procedures, tools and quality attributes. There are three general possible dimensions for PMM concept analysis: the actions (skills to act and decide), the behaviors or attitudes (desire to be involved) and knowledge (understanding the impacts of the relationship between attitudes and actions). The resultant dimension in the business environment usually defines the PMM level in for the organization (Andersen and Jessen, 2007).

From the 1990's, several PMM models has been developed. From the Capability Maturity Model which one has been continuously improved and updated. Nowadays, it is referred as the Capability Maturity Model Integration (CMMI). As most of PMM models, CMMI includes five levels: Initial Level, Repeatable Level, Defined Level, Managed Level, and Optimizing Level (Chrissis et al., 2006).

According to Kerzner (2009), the Maturity model is part of the pursuit of excellence in Project Management. The Kerzner PMM Model was selected to perform the survey for this study. This model was chosen once it is aligned to CMMI, authored by highly credible, highly applied in PM, public, high likelihood of good response rate to a survey, questionnaire with the least number of questions when compared with other similar existing models, uses the 9 PM knowledge areas in accordance with the PMBOK (2008) from and finally presents an approach compatible with the standards of excellence required by organizations. Kerzner's Project Management Maturity Model (KPMMM, is also composed by five levels: Embryonic, Executive Management Acceptance, Line Management Acceptance, Growth, and Maturity. CMMI and KPMMM have other important similarities. Both of them are very popular in the professional environment, and they have authors of good credibility and reputation. But, the greatest similarity between CMMI and KPMMM is that the main framework of both models looks like a stair, as presented in Figure 1.

Every level of PMM is a stair step. The meaning of the stair steps is that to have its PMM classified in a level, a company must satisfy the requirements to this level, and also the requirements to previous level. So, for instance, if a company satisfies Level 1 and 2 requirements, but, does not satisfy Level 3 requirements, it must be classified in the Level 2 of PMM. 


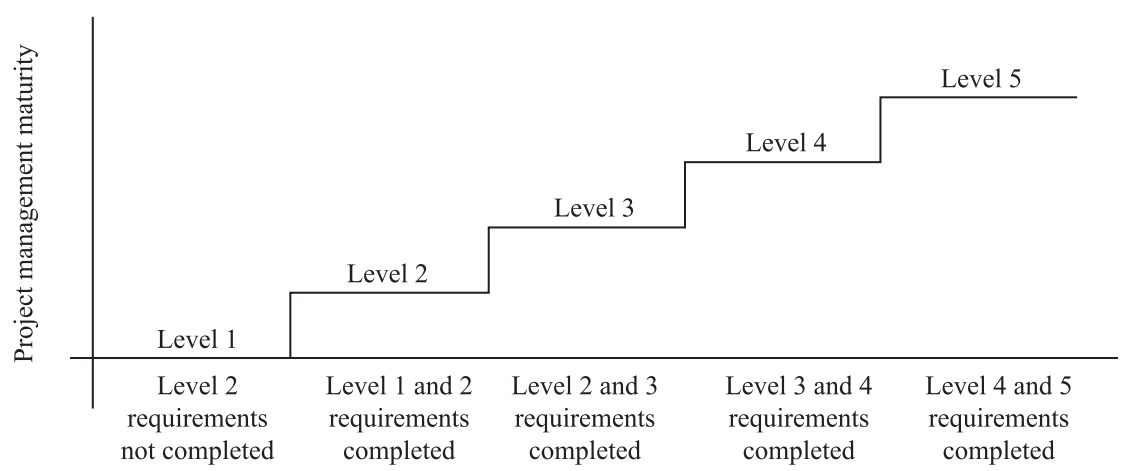

Figure 1. Five-level Project Management Maturity Model Framework.

To determine in which level of PMM the company must be classified, most of PMM models use questionnaires. A great advantage of KPMMM is that its questionnaire has only 20 questions. The model proposed by Ibbs and Kwak (2000), for instance, has 148 questions. The 20 questions from the KPMMM are distributed in the five levels of PMM, but, in random order, as presented and grouped as shown in Table 1.

For instance, KPMMM's Question 1 is "My company recognizes the need for project management. This need is recognized at all levels of management, including senior management" (Kerzner, 2003). The respondent of KPMMM's questionnaire must choose an answer from the scale presented in Table 2 . With +3 points in all four questions, the 3 maximum per level of PMM is equal to +12 points. Based on this, Kerzner (2001) proposed that with +6 points, level requirements are satisfied.

The KPMMM's original scale, from -3 to +3 , has no scientific basis, instead of 1 to 5 (Likert, 1932), or 1 to 9 (Saaty, 1977). The lower limit of +6 points to consider level requirements satisfied is equally subjective. To investigate this subjectivity and to deal with situations of inconsistency in the PMM, a Fuzzy Expert System was developed, as presented in Section 3.

\section{Fuzzy Expert System}

As observed by Kerzner (2009), certain levels of PMM do overlaps. The PMM evolution is not always sequential. Companies can be working on more than one levels of PMM, at the same time. For example, a company can make some efforts in project management satisfying Level 2 requirements, while many Level 1 requirements were not yet satisfied. In this case, company's answers to KPMMM's questionnaire may score +6 points to Level 1 , and +5 points to Level 2 . These scores result in a classification as Level 1 of PMM. But, it is a Level 1, almost in Level 2. This way, as it will be explained in this section, it seems that Fuzzy Sets Theory can help companies to better understand their actual PMM.

The Fuzzy Sets Theory, proposed by Zadeh (1965), has provided excellent tools to deal with ambiguity or vagueness (Yen, 1999). In classical sets theory, elements either belong to a set, or not. In Fuzzy Sets Theory, elements can belong to a set with a certain degree (Bobillo et al., 2009). This degree is more formally referred as 
Table 1. Questions on the PM Maturity by level (Kerzner, 2001, 2003).

\begin{tabular}{|c|c|c|c|c|c|}
\hline Level & 1 & 2 & 3 & 4 & 5 \\
\hline Questions & $\begin{array}{l}1,3,14 \text {, } \\
\text { and } 17\end{array}$ & $\begin{array}{c}5,10,13, \\
\text { and } 20\end{array}$ & $\begin{array}{l}7,9,12 \\
\text { and } 19\end{array}$ & $4,6,8$, and 11 & $2,15,16$, and 18 \\
\hline \multicolumn{6}{|c|}{ Kerzner Model Questionnaire } \\
\hline \multicolumn{4}{|c|}{$\begin{array}{l}\text { 1. My company recognizes the need for project } \\
\text { management. This need is recognized at all levels } \\
\text { of management, including senior management. }\end{array}$} & \multicolumn{2}{|c|}{$\begin{array}{l}\text { 2. My company has a system in place to } \\
\text { manage both cost and schedule. The project } \\
\text { management maturity questionnaire system } \\
\text { requires charge numbers and cost account } \\
\text { codes. The system reports variances from } \\
\text { planned targets. }\end{array}$} \\
\hline \multicolumn{4}{|c|}{$\begin{array}{l}\text { 3. My company has recognized the benefits } \\
\text { that are possible from implementing project } \\
\text { management. These benefits have been } \\
\text { recognized at all levels of management, including } \\
\text { senior management. }\end{array}$} & \multicolumn{2}{|c|}{$\begin{array}{l}\text { 4. My company (or division) has a well- } \\
\text { definable project management methodology } \\
\text { using life cycle phases. }\end{array}$} \\
\hline \multicolumn{4}{|c|}{$\begin{array}{l}\text { 5. Our executives visibly support project } \\
\text { management through executive presentations, } \\
\text { correspondence, and by occasionally attending } \\
\text { project team meetings/briefings. }\end{array}$} & \multicolumn{2}{|c|}{$\begin{array}{l}\text { 6. My company is committed to quality } \\
\text { up-front planning. We try to do the best we } \\
\text { can at planning. }\end{array}$} \\
\hline \multicolumn{4}{|c|}{$\begin{array}{l}\text { 7. Our lower and middle-level line managers } \\
\text { totally and visibly support the project } \\
\text { management process. }\end{array}$} & \multicolumn{2}{|c|}{$\begin{array}{l}\text { 8. My company is doing everything possible } \\
\text { to minimize "creeping" scope (i.e., scope } \\
\text { changes) on our projects. }\end{array}$} \\
\hline \multicolumn{4}{|c|}{$\begin{array}{l}\text { 9. Our line managers are committed not only to } \\
\text { project management, but also to the promises } \\
\text { made to project managers for deliverables. }\end{array}$} & \multicolumn{2}{|c|}{$\begin{array}{l}\text { 10. The executives in my organization have } \\
\text { a good understanding of the principles of } \\
\text { project management. }\end{array}$} \\
\hline \multicolumn{4}{|c|}{$\begin{array}{l}\text { 11. My company has selected one or more project } \\
\text { management software packages to be used as the } \\
\text { project tracking system. }\end{array}$} & \multicolumn{2}{|c|}{$\begin{array}{c}\text { 12. Our lower and middle-level line managers } \\
\text { have been trained and educated in project } \\
\text { management. }\end{array}$} \\
\hline \multicolumn{4}{|c|}{$\begin{array}{l}\text { 13. Our executives both understand project } \\
\text { sponsorship and serve as project sponsors on } \\
\text { selected projects. }\end{array}$} & \multicolumn{2}{|c|}{$\begin{array}{l}\text { 14. Our executives have recognized or } \\
\text { identified the applications of project } \\
\text { management to various parts of our business. }\end{array}$} \\
\hline \multicolumn{4}{|c|}{$\begin{array}{l}15 . \text { My company has successfully integrated cost } \\
\text { and schedule control together for both managing } \\
\text { projects and reporting status. }\end{array}$} & \multicolumn{2}{|c|}{$\begin{array}{l}\text { 16. My company has developed a project } \\
\text { management curriculum (i.e., more than } \\
\text { one or two courses) to enhance the project } \\
\text { management skills of our employees. }\end{array}$} \\
\hline \multicolumn{4}{|c|}{$\begin{array}{l}\text { 17. Our executives have recognized what must } \\
\text { be done in order to achieve maturity in project } \\
\text { management. }\end{array}$} & \multicolumn{2}{|c|}{$\begin{array}{l}\text { 18. My company views and treats project } \\
\text { management as a profession rather than a } \\
\text { part-time assignment. }\end{array}$} \\
\hline \multicolumn{4}{|c|}{$\begin{array}{l}\text { 19. Our lower and middle-level line managers } \\
\text { are willing to release their employees for project } \\
\text { management training. }\end{array}$} & \multicolumn{2}{|c|}{$\begin{array}{c}\text { 20. Our executives have demonstrated a } \\
\text { willingness to change our way of doing } \\
\text { business in order to mature in project } \\
\text { management. }\end{array}$} \\
\hline
\end{tabular}


Table 2. Answers and Scores to KPMMM's questionnaire (Kerzner, 2003).

\begin{tabular}{|c|c|}
\hline Answer & Score \\
\hline Strong disagree & -3 \\
\hline Disagree & -2 \\
\hline Slightly disagree & -1 \\
\hline No opinion & 0 \\
\hline Slightly agree & +1 \\
\hline Agree & +2 \\
\hline Strong agree & +3 \\
\hline
\end{tabular}

membership. Every Fuzzy Set, $A$, is characterized by a membership function, $\mu A(x)$, which associates every element, $x$, to a real number in the interval $[0,1]$. As in classical theory, $\mu A(x)=0$ means no-membership, and $\mu A(x)=1$ means full-membership.

The establishment of a membership functions is a process referred as Fuzzification (Saleh and Kim, 2009). Several membership functions are used in practice. Triangular Membership Function is commonly used because of its simplicity and easy computation. As presented in Figure 2, a Triangular Fuzzy Set (TFS) has a Triangular Membership Function. A TFS is usually represented as a vector, $(\alpha, \beta, \gamma)$, where $\mu A(\alpha)=\mu A(\gamma)=0$, and $\mu A(\beta)=1$.

A Fuzzy Expert System consists of a database of facts and a database of rules (Yen, 1999). One of the most popular Expert Systems is the Mamdani Model (Bobillo et al., 2009). In a Mamdani Model there are If-Then rules of the type: If $A$ Then $B$, where all $A$ and $B$ are fuzzy propositions.

These propositions must be established by experts. For every clause in the rule, the matching degree, $\mu A(x)$, between the current value for the variable and a linguistic label must be computed. The clauses are aggregated, using the Minimum Fuzzy Operator. If more than one rule implies in the same result, the rules are aggregated, using the Maximum Fuzzy Operator. The overall matching degree can be obtained, also using the Minimum Fuzzy Operator. This degree is referred as alpha-cut, or $\alpha$-cut (Bertoluzza et al., 2001). The $\alpha$-cut level will generate a new Fuzzy Set, with a Trapezoidal Membership Function, as presented in Figure 3. A real number may be obtained from the Centroid of Gravity $(C O G)$ of the resulting Fuzzy Set, within a process referred as Defuzzification.

KPMMM adopts the score of +6 as the lower limit to consider level requirements satisfied. To deal with this subjectivity with Fuzzy Expert System, two TFS are proposed: No Pass, $(-12,-12,+8)$, and Pass,$(+4,+12,+12)$, as presented in Figure 4. These TFS will be used in the Fuzzy Expert System for every level of PMM.

Another subject that an Expert System can deal is the situation of inconsistency obtained by the response to KPMMM's questionnaire. Table 3 presents 32 rules developed for every possible situation. That is, a response according to Rule 2 must be considered as Inconsistent, since Levels 1 to 4 requirements were not satisfied, but Level 5 requirements were satisfied. 


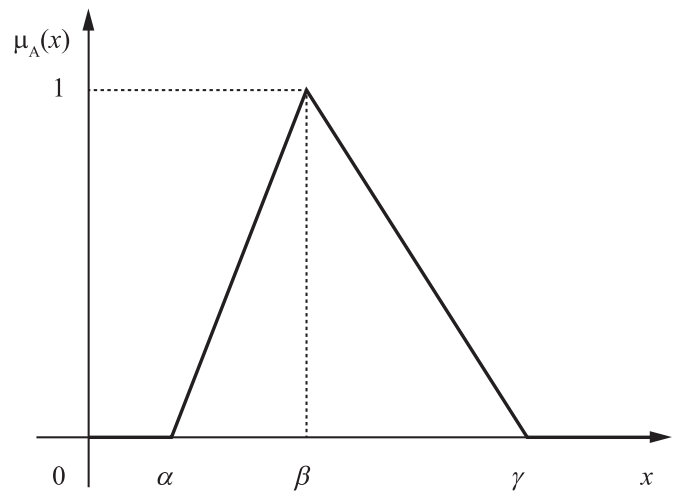

Figure 2. Triangular Fuzzy Set.

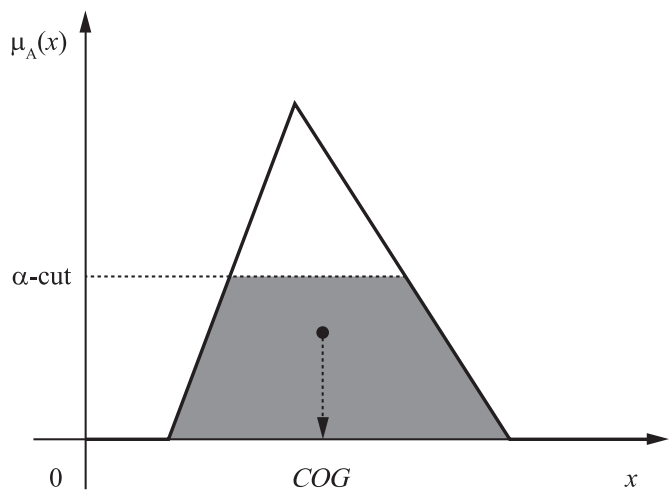

Figure 3. Defuzzification by the Centroid of Gravity.

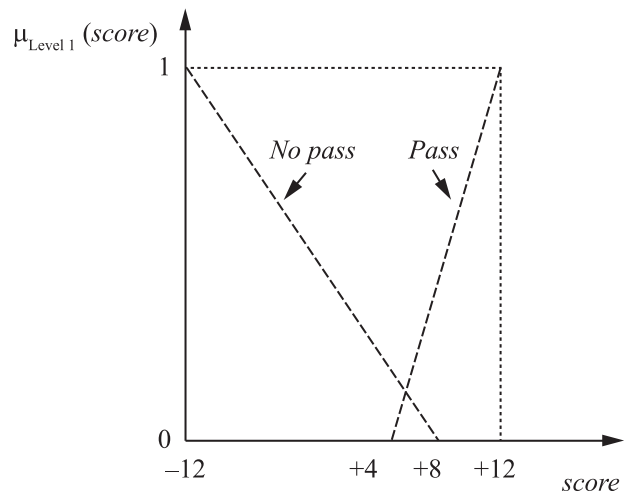

Figure 4. Fuzzy Sets Pass and No Pass for Level 1 of PMM. 
Table 3. Expert for a five-level PM Maturity Questionnaire.

\begin{tabular}{|c|c|c|c|c|c|c|}
\hline Rule & Level 1 & Level 2 & Level 3 & Level 4 & Level 5 & Situation \\
\hline 1 & No Pass & No Pass & No Pass & No Pass & No Pass & Consistent \\
\hline 2 & No Pass & No Pass & No Pass & No Pass & Pass & Inconsistent \\
\hline 3 & No Pass & No Pass & No Pass & Pass & No Pass & Inconsistent \\
\hline 4 & No Pass & No Pass & No Pass & Pass & Pass & Inconsistent \\
\hline 5 & No Pass & No Pass & Pass & No Pass & No Pass & Inconsistent \\
\hline 6 & No Pass & No Pass & Pass & No Pass & Pass & Inconsistent \\
\hline 7 & No Pass & No Pass & Pass & Pass & No Pass & Inconsistent \\
\hline 8 & No Pass & No Pass & Pass & Pass & Pass & Inconsistent \\
\hline 9 & No Pass & Pass & No Pass & No Pass & No Pass & Inconsistent \\
\hline 10 & No Pass & Pass & No Pass & No Pass & Pass & Inconsistent \\
\hline 11 & No Pass & Pass & No Pass & Pass & No Pass & Inconsistent \\
\hline 12 & No Pass & Pass & No Pass & Pass & Pass & Inconsistent \\
\hline 13 & No Pass & Pass & Pass & No Pass & No Pass & Inconsistent \\
\hline 14 & No Pass & Pass & Pass & No Pass & Pass & Inconsistent \\
\hline 15 & No Pass & Pass & Pass & Pass & No Pass & Inconsistent \\
\hline 16 & No Pass & Pass & Pass & Pass & Pass & Inconsistent \\
\hline 17 & Pass & No Pass & No Pass & No Pass & No Pass & Consistent \\
\hline 18 & Pass & No Pass & No Pass & No Pass & Pass & Inconsistent \\
\hline 19 & Pass & No Pass & No Pass & Pass & No Pass & Inconsistent \\
\hline 20 & Pass & No Pass & No Pass & Pass & Pass & Inconsistent \\
\hline 21 & Pass & No Pass & Pass & No Pass & No Pass & Inconsistent \\
\hline 22 & Pass & No Pass & Pass & No Pass & Pass & Inconsistent \\
\hline 23 & Pass & No Pass & Pass & Pass & No Pass & Inconsistent \\
\hline 24 & Pass & No Pass & Pass & Pass & Pass & Inconsistent \\
\hline 25 & Pass & Pass & No Pass & No Pass & No Pass & Consistent \\
\hline 26 & Pass & Pass & No Pass & No Pass & Pass & Inconsistent \\
\hline 27 & Pass & Pass & No Pass & Pass & No Pass & Inconsistent \\
\hline 28 & Pass & Pass & No Pass & Pass & Pass & Inconsistent \\
\hline 29 & Pass & Pass & Pass & No Pass & No Pass & Consistent \\
\hline 30 & Pass & Pass & Pass & No Pass & Pass & Inconsistent \\
\hline 31 & Pass & Pass & Pass & Pass & No Pass & Consistent \\
\hline 32 & Pass & Pass & Pass & Pass & Pass & Consistent \\
\hline
\end{tabular}


The membership values for every level of PMM must be aggregated. With the Minimum Fuzzy Operator, the $\alpha$-cut will be obtained. Two TFS are proposed: Consistent $(0.6,1,1)$, and Inconsistent $(0,0,0.6)$, as presented in Figure 5. This way, $60 \%$ is proposed as a lower limit for a consistent response.

Figure 6 presents the inputs and outputs of the Fuzzy Expert System developed to KPMMM. The answers from a project manager to KPPMM's questionnaire are the first inputs to the Expert System. The TFS presented in Figures 4 and 5 are other inputs. The Expert System has two outputs. The PMM classification is the first output. The consistency of this classification is the second output. In Section 4, it is presented an illustrative example of the Fuzzy Expert System application. The object is the PMM of Brazilian companies.

\section{A Real Application of the Developed Fuzzy Expert System}

At the end of 2009, project managers registered at the PMI's Sao Paulo Chapter were contacted. They were invited to make part of a survey on the PMM of Brazilian companies. Based on KPMMM, a website was developed for the survey. The website was hosted in a server from Federal University of Itajuba. With the association of the survey to these two well known institutions, it was expected a high index of response. Two other procedures were carried out to stimulate the respondents. The participant anonymousness was guaranteed. That is, the participants and their companies

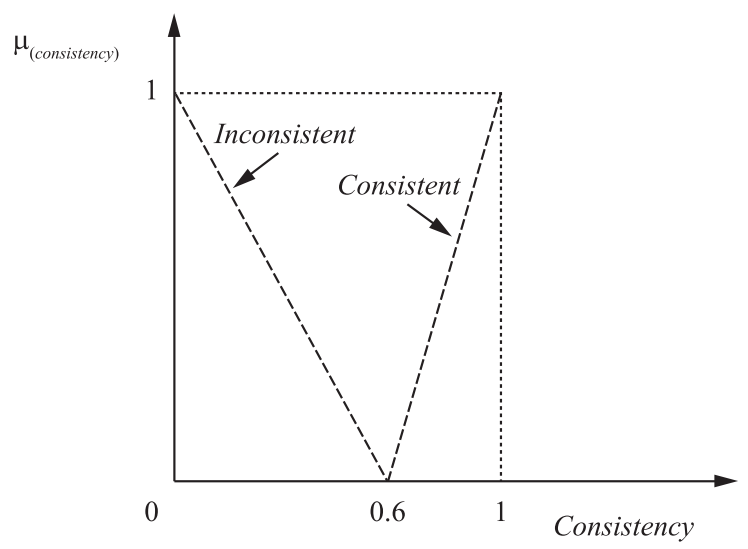

Figure 5. Fuzzy Sets Consistent and Inconsistent for questionnaire's responses.

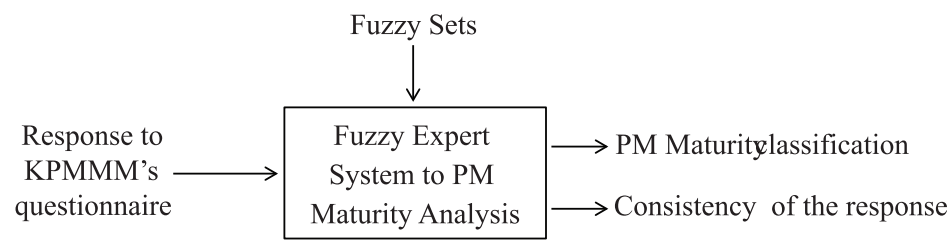

Figure 6. Fuzzy Expert System proposed for KPMMM. 
will not be identified. And, only the respondents will have access to results from the survey. Unfortunately, only 101 completed answers to survey were received. As it represents more than 5\% for a 1,000 higher population, this sample does have statistical meaning. More important than that, the sample has good distribution, according to various attributes, as it will be following commented. This variation does strength a multivariate data analysis (Hair et al., 2009).

On the 101 respondents of the survey, 66 were from service companies, against 35 from manufacturing companies; only 41 were from multinational corporations; 31 were from petrochemical industry, 16 from consulting companies, 15 from metallurgical industry, 14 from information technology and telecommunications companies, and other 25 were from various sectors, including automotive and aerospace industry, and healthcare companies; 57 were from companies with more than 1,000 direct workers, but, 7 were from companies with less than 50 employees.

Table 4 presents 10 first responses received in the survey. PMM for Responses 1 to 3 are classified as Level 1 according to KPMMM and the Fuzzy Expert System. The responses diverge in their consistency indices. Response 3 has a score greater than +4 for Level 4 , and smaller scores for lower levels. So, the consistency index of Response 3 is equal to 0.386 , that is, smaller than 0.6 . This is an indication for the company that its efforts were not aligned with KPMMM. The company was possibly spending more resources with higher levels requirements, while it did not satisfy lower levels requirements.

Table 4 was obtained using the software Matlab ${ }^{\circledR}$. The 32 possible rules are introduced to the Fuzzy Expert System in the Matlab ${ }^{\circledR}$, and then the survey results are also input into the system in order to check the final response considering the Fuzzy Set conditions. Table 4 also compares the usual crisp result using the Kerzner model and the results after the application Fuzzy Expert System. Matlab® calculates the consistency based on the Fuzzy System explained in Section 3.

Table 4. Some responses received for the survey.

\begin{tabular}{|c|c|c|c|c|c|c|c|c|}
\hline \multirow[t]{2}{*}{ Response } & \multirow{2}{*}{$\begin{array}{c}\text { Level } \\
1\end{array}$} & \multirow{2}{*}{$\begin{array}{c}\text { Level } \\
2\end{array}$} & \multirow{2}{*}{\begin{tabular}{|c} 
Level \\
3
\end{tabular}} & \multirow{2}{*}{$\begin{array}{c}\text { Level } \\
4\end{array}$} & \multirow{2}{*}{\begin{tabular}{|c} 
Level \\
5
\end{tabular}} & \multirow{2}{*}{$\begin{array}{c}\text { Crisp } \\
\text { PM Maturity } \\
\text { Classification }\end{array}$} & \multicolumn{2}{|c|}{ Fuzzy Expert System's } \\
\hline & & & & & & & $\begin{array}{l}\text { PM Maturity } \\
\text { Classification }\end{array}$ & Consistency \\
\hline 1 & -7 & -7 & -4 & 1 & -6 & Level 1 & Level 1 & 0.835 \\
\hline 2 & -7 & -4 & -7 & -3 & -4 & Level 1 & Level 1 & 0.851 \\
\hline 3 & 3 & 0 & -4 & 6 & 1 & Level 1 & Level 1 & 0.386 \\
\hline 4 & 7 & 8 & 3 & 7 & 2 & Level 2 & Level 2 & 0.333 \\
\hline 5 & 7 & 6 & 4 & 6 & 4 & Level 2 & Level 5 & 0.411 \\
\hline 6 & 5 & 6 & 8 & 7 & 5 & Level 1 & Level 5 & 0.470 \\
\hline 7 & 9 & 8 & 6 & 9 & 7 & Level 5 & Level 5 & 0.613 \\
\hline 8 & 8 & 7 & 8 & 7 & 7 & Level 5 & Level 5 & 0.732 \\
\hline 9 & 6 & -2 & 4 & -1 & -8 & Level 1 & Level 1 & 0.822 \\
\hline 10 & -3 & -3 & -1 & -5 & -2 & Level 1 & Level 1 & 0.843 \\
\hline$\ldots$ & $\ldots$ & $\ldots$ & $\ldots$ & $\ldots$ & $\ldots$ & $\ldots$ & $\ldots$ & $\ldots$ \\
\hline
\end{tabular}


In contrast, PMM for Responses 5 to 8 are classified as Level 5 according to Fuzzy Expert System. However, Responses 5 and 6 are respectively classified as Level 2 and Level 1 according to KPMMM. This divergence was due to scores equal to +4 or +5 for lower levels than Level 5 . The consequence was consistency indices lower than 0.6 for Responses 5 and 6. As the scores for all levels in Responses 7 and 8 are greater than or equal to +6 , they are both classified as Level 5 according to KPMMM and the Fuzzy Expert System. And their consistency indices are greater than 0.6. The analysis for Responses 5 and 6 is the same for Response 3: satisfaction of higher levels requirements, and no satisfaction of lower levels.

The average consistency index for all 101 respondents is 0.64 . In addition, $61 \%$ of responses have a consistency index greater than 0.6 . This result suggests that most respondents have aligned their efforts with KPMMM. According to KPMMM, alone, Level 1 is the level with more respondents: 47 companies. This is a frustrating result, since it is the starting level of PMM. With the new +4 lower limit, and 66 respondents, according to the Fuzzy Experts Systems there are more companies classified in Level 2 than any other level. This seems to be a more suitable result, since the participation in the survey implies in knowledge and interest to Project Management. That is, the PMM of a company who provides consistent answers to a questionnaire may be classified in level higher than Level 1. To provide a sensitivity analysis, the Fuzzy Sets proposed in Figure 5 were varied. Changing the consistency limit from 0.6 to $0.5,75 \%$ of the responses are consistent. Changing the limit to 0.7 , only $54 \%$ will remain consistent. So, the consistency limit is an important input from experts when the proposed expert system will be applied.

The respondents were contacted, and informed on the main results, and also the level of PMM obtained from their individual responses, and its respective consistency. Three of them will be further studied with forthcoming case studies.

\section{Conclusions and Discussions}

In this paper, a Fuzzy Expert System is proposed to PMM analysis. PMM models have some fuzzy aspects like the overlapping between maturity levels. This way, incorporate the fuzzyness of sets as the satisfaction of level requirements, seemed to be most proper than using subjective crisp classifications.

The proposed Fuzzy Expert System is very simple to be implemented, even in spreadsheets. It is composed of only 32 rules, and three limits to be provided by experts: the upper no-pass, and the lower pass limits to levels of PMM, and the consistency limit. This Expert System was applied in a survey with Brazilian companies. The analysis of the results with the expert systems seemed to better represent the reality.

For project managers, a great practical benefit of using Expert Systems, after checking the consistency of its PMM classification, is to guide their organizations to an alignment with an established project management theory as the KPMMM. As a future research, case 6 studies are now being conducted with some respondents of the survey. The consistency of their responses will be a major theme in this investigation. 


\section{Acknowledgements}

To PMI's Sao Paulo Chapter, for the survey promotion. To Prof. Harold Kerzner, who promptly shared his opinions on the subjects regarding the survey and this work.

\section{References}

Andersen, E.S. and Jessen, S.A. (2007) A Quick Project Maturity Assessment, in: PMI Global Congress Proceedings, Hong Kong, CID 8504, TRN011.

Andersen, E.S. and Jessen, S.A. (2003) Project Maturity in Organizations. International Journal of Project Management, Vol. 21, No. 6, pp. 457-462.

Bertoluzza, C.; Solcia, M. and Capodieci, M.L. (2001) Measure of a fuzzy set. The $\alpha$-cut approach in the finite case. Fuzzy Sets and Systems, Vol. 123, pp. 93-102. http://dx.doi. org/10.1016/S0165-0114(00)00074-9

Bobillo, F.; Delgado, M. and Gómez-Romero, J. (2009) A semantic fuzzy expert system for a fuzzy balanced scorecard. Expert Systems with Applications, Vol. 36, pp. 423-433. http://dx.doi.org/10.1016/j.eswa.2007.09.020

Brookes, N. and Clark, R. (2009) Using Maturity Models to Improve Project Management Practice, in: $20^{\text {th }}$ Annual Conference, POMS - Production and Operations Management Society, pp. 11-288.

Chrissis, M.B.; Konrad, M. and Shrum, S. (2006) CMMI Guidelines for Process Integration and Product Improvement. 2nd ed. Reading: Addison-Wesley.

Hair, J.F.; Black, W.C.; Babin, B.J. and Anderson, R.E. (2009) Multivariate Data Analysis. 3rd ed. Englewood Cliffs: Prentice Hall.

Hartman, F. and Skulmoski, G. (2000) Project management maturity. Project Management, Vol. 98, pp. 74-78.

Hayes, J. (2007) The Theory and Practice of Change Management. 2nd ed.

Hillson, D. (2003) Assessing organizational Project Management capability. Journal of Facilities Management, Vol. 2, No. 3, pp. 298-311. http://dx.doi.org/10.1108/14725960410808276

Ibbs, C.W. and Kwak, Y.H. (2000) Assessing project management maturity. Project Management Journal, Vol. 31, pp. 32-43.

Jiang, J.J.; Klein, G.; Hwang H.-G.; Huang, J. and Hung S.-Y. (2004) An Exploration of the relationship between software development process Maturity and project performance. Information \& Management, Vol. 41, No. 1, pp. 279-288. http://dx.doi.org/10.1016/S03787206(03)00052-1

Kerzner, H. (2001) Strategic Planning for Project Management using a Project Management Maturity Model. Hoboken: Wiley.

Kerzner, H. (2003) Project Management Workbook to Accompany Project Management: a system approach to planning, scheduling and controlling. 8th ed. Hoboken: Wiley.

Kerzner, H. (2009) Project Management: a system approach to planning, scheduling and controlling. 10th ed. Hoboken: Wiley.

Likert, R. (1932) A Technique for the measurement of attitudes. Archives of Psychology, Vol. 140, pp. 1-55.

Paulk, M.C.; Curtis, B.; Chrissis, M.B. and Weber, C.V. (1993) CMMI, Technical report CMU/SEI-93-TR-24. Pittsburgh: Carnegie Mellon University.

Saaty, T.L. (1977) A scaling method for priorities in hierarchical structures. Journal of Mathematical Psychology, Vol. 15, pp. 234-281. http://dx.doi.org/10.1016/0022-2496(77)90033-5 
Saleh, I. and Kim, S. (2009) A fuzzy system for evaluating students' learning achievement. Expert Systems with Applications, Vol. 36, pp. 6236-6243. http://dx.doi. org/10.1016/j.eswa.2008.07.088

Sawaya, N. and Trapanese, P. (2004) Measuring Project Management Maturity. SDM, Vol. 34, No. 1, pp. 44-46.

Yen, V.C. (1999) Rule selections in fuzzy expert systems. Expert Systems with Applications, Vol. 16, pp. 79-84. http://dx.doi.org/10.1016/S0957-4174(98)00024-4

Zadeh, L.A. (1965) Fuzzy sets. Information and Control, Vol. 8, pp. 338-353. http:// dx.doi.org/10.1016/S0019-9958(65)90241-X

\section{Biography}

Helder Jose Celani de Souza, Ph.D. in Production Engineering at Sao Paulo State University, Brazil, PMP Certified by PMI - USA, Certified in Lean Manufacturing by University of Michigan, USA, MBA at FGV-RJ, Brazil, Post-graduate degree in Project Management at Vanzolini / USP, Brazil, Master \& Graduation Degree in Electrical Engineering at Federal University of Itajubá, Brazil, Post-graduated in Electrical Engineering at University of Campinas, Brazil, Project Manager at Siemens Heatlhcare Diagnostics in Brazil.

Contact: hcelani@uol.com.br

Valerio Antonio Pamplona Salomon, Professor at Sao Paulo State University - UNESP in Guaratingueta, Brazil, Post-doctorate in Decision-Making at the University of Pittsburgh (PITT), Ph.D. in Production Engineering at the University of São Paulo -USP in Sao Paulo, Brazil), Master \& Production Engineering degree in Mechanical Engineering at Federal School of Engineering Itajubá - UNIFEI in Itajuba, Brazil. Board Member of the Foundation for Scientific and Technological Development (FDCT).

Contact: salomon@feg.unesp.br

Carlos Eduardo Sanches da Silva, Professor at Federal University of Itajuba, Itajuba, Brazil, Researcher in Project Management and Product Development. Technical Committee Member of FAPEMIG, CAPES and Engineering and Scientific Director III at ABEPRO in Brazil. Economist, Mechanical Engineer, Specialist in Quality and Productivity, Master in Production Engineering, Ph.D. in Production Engineering, Post-doctoral fellow University of Texas.

Contact: cadusanches@uol.com.br

Dimas Campos Aguiar, graduated in Mechanical Engineering at the University of Taubate in Taubate, Brazil (1999) and Master Degree in Mechanical Engineering obtained at the Sao Paulo State University in Guaratinguetá, Brazil (2007). Experience in Production Engineering focused on Quality Engineering, Suppliers Management, Quality Management for the Automotive Sector.

Contact:dimas_c@hotmail.com

\section{Article Info:}

Received: September, 2011

Accepted: September, 2012 